\title{
IL10 wt Allele
}

National Cancer Institute

\section{Source}

National Cancer Institute. IL10 wt Allele. NCI Thesaurus. Code C49787.

Human IL10 wild-type allele is located within 1q31-q32 and is approximately $5 \mathrm{~kb}$ in length.

This allele, which encodes interleukin-10 protein, plays a role in several processes such as immune regulation and inflammation. 